\title{
CHEMOSPHERE
}

\section{Effect of glyphosate on the microbial activity of two Brazilian soils}

\author{
A.S.F. Araújo ${ }^{\text {a }}$, R.T.R. Monteiro ${ }^{\mathrm{a}, *}$, R.B. Abarkeli ${ }^{\mathrm{b}}$ \\ a Centro de Energia Nuclear na Agricultura, Caixa Postal P.O. Box 96, Piracicaba, SP 13400-970, Brazil \\ ${ }^{\mathrm{b}}$ EMBRAPA-Meio Ambiente, P.O. Box 69, Jaguaríuna, SP 13820-000, Brazil
}

Received 28 August 2002; received in revised form 21 February 2003; accepted 21 February 2003

\begin{abstract}
Glyphosate [ $N$-(phosphonomethyl)-glycine] is a broad-spectrum, non-selective, post-emergence herbicide that is widely used in agricultural. We studied, in vitro, changes in the microbial activity of typical Hapludult and Hapludox Brazilian soils, with and without applied glyphosate. Glyphosate was applied at a rate of $2.16 \mathrm{mg}$ glyphosate $\mathrm{kg}^{-1}$ of soil and microbial activity was measured by soil respiration (evolution of $\mathrm{CO}_{2}$ ) and fluorescein diacetate (FDA) hydrolysis over a period of 32 days. We found an increase of $10-15 \%$ in the $\mathrm{CO}_{2}$ evolved and a $9-19 \%$ increase in FDA hydrolyses in the presence of glyphosate compared with the same type of soil which had never received glyphosate. Soil which had been exposed to glyphosate for several years had the strongest response in microbial activity. Most probable number (MPN) counts showed that after 32 days incubation the number of actinomycetes and fungi had increased while the number of bacteria showed a slight reduction. After the incubation period, high pressure liquid chromatography (HPLC) detected the glyphosate metabolite aminomethyl phosphonic acid (AMPA), indicating glyphosate degradation by soil microorganisms.
\end{abstract}

(c) 2003 Elsevier Science Ltd. All rights reserved.

Keywords: Biodegradation; Herbicide; Oxisol; Ultisol

\section{Introduction}

In recent years, the intensive use of herbicides has increasingly become a matter of environmental concern, partially because of the adverse effects of these chemicals on soil microorganisms. Glyphosate [ $N$-(phosphonomethyl)glycine] is a broad-spectrum, non-selective, postemergence herbicide that is widely used in agriculture. The commercial success of glyphosate as a highly effective herbicide has stimulated several studies on its behavior and persistence in soil (Krzysko-Lupicka and Orlik, 1997; Forlani et al., 1999; Jonge and Jonge, 1999).

\footnotetext{
*Corresponding author. Tel.: +55-19-3429-4761/4600; fax: $+55-19-3429-4610$.

E-mail address: monteiro@cena.usp.br (R.T.R. Monteiro).
}

Microbial degradation is considered to be the most important of the transformation processes that determine the persistence of herbicides in soil (Souza et al., 1999). In the case of glyphosate, Wiren-Lehr et al. (1997) observed that mineralization of this herbicide is related to the both the activity and biomass of soil microorganisms. Microbial degradation of glyphosate produces the major metabolite aminomethyl phosphonic acid (AMPA), and ultimately leads to the production of water, carbon dioxide and phosphate (Forlani et al., 1999).

The presence of glyphosate in soil may cause changes to the microbial population and activity of a soil. Wardle and Parkinson (1990a,b) observed that the presence of glyphosate in a soil was related to a temporary increase in the both number of bacteria in a soil and the overall microbial activity of the soil, although the number of 
fungi and actinomycetes was not affected. On the other hand, in studying the effect of glyphosate on the number of microorganisms in a soil, microbial biomass and soil respiration Stratton and Stewart (1992) observed only a small increase in microbial biomass but no negative or positive effects in respect to the number of microorganism or soil respiration. More recently, Haney et al. (2000) and Busse et al. (2001) evaluated the effect of glyphosate on the microbial community of soils and observed that microbial activity was stimulated in the presence of this herbicide.

The aim of the work presented in this paper was to evaluate the effects of glyphosate on microbial activity in two soil types (with and without a previous history of glyphosate application) and determine which groups of microorganisms were most active.

\section{Material and methods}

\subsection{Soil samples}

Two different soil types were collected from fields with and without a reported history of glyphosate application. One soil type was collected from a peach orchard at the experimental station of Escola Superior de Agricultura Luiz de Queiroz (ESALQ), Piracicaba-São Paulo, Brazil and classified as a typical Hapludult (HT) Brazilian soil. Soil samples were collected from the surface layer of the soil up to a depth of $10 \mathrm{~cm}$, in an area no reported application of glyphosate (samples HTG0) and an adjacent area with six years application of glyphosate (sample HTG6). The other soil type was collected at the experimental station of Instituto Agronômico do Paraná (IAPAR), Londrina-Paraná, Brazil and classified as a typical Hapludox (HX) Brazilian soil. Soil samples without reported application of glyphosate (samples HXG0) were collected from a banana orchard and those with 11 years of application of glyphosate (HXG11) from a no-tillage soybean field. The principal characteristics of the soils are shown in Table 1.

\subsection{Biodegradation of glyphosate}

A solution of technical glyphosate (analytical standard) sufficient to give a final glyphosate concentration of $2.16 \mathrm{mg} \mathrm{kg}^{-1}$ was added to $75 \mathrm{~g}$ sub-samples of soil, which were then incubated in flasks in the dark for 32 days at $25{ }^{\circ} \mathrm{C}$. Soil moisture content was adjusted to two-thirds of the field capacity. Biodegradation of glyphosate was evaluated by the carbon dioxide evolution method using the procedure described by Bartha and Pramer (1965). Carbon dioxide evolution was monitored at 2, 4, 8, 16, 24 and 32 days after glyphosate application.

\subsection{Soil microbial activity}

Soil microbial activity was evaluated by measuring fluorescein diacetate (FDA) hydrolysis according to the method of Schnürer and Rosswall (1982).

\subsection{Enumeration of microorganisms}

Bacteria, fungi and actinomycetes were enumerated, by the plate counts method (Jahnel et al., 1999), at the start and end of incubation period. $10 \mathrm{~g}$ (dry weight) of soil samples was used to provide a dilution series of $10^{-3}, 10^{-4}, 10^{-5}, 10^{-6}$ and $10^{-7}$. For bacterial counts, 0.1 $\mathrm{ml}$ of each of the $10^{-4}, 10^{-5}, 10^{-6}$ and $10^{-7}$ dilution were added to each of 5 nutrient agar spread-plates. For actinomycetes counts, $0.1 \mathrm{ml}$ of each of the $10^{-3}, 10^{-4}$, $10^{-5}$ and $10^{-6}$ dilution were added to 5 casein agar spread-plates. Fungal propagules counts were determined from the same four dilution by using 5 malt extract agar spread-plates with $100 \mu \mathrm{gg}^{-1}$ streptomycin and $50 \mu \mathrm{g} \mathrm{g}^{-1}$ aureomycin. The plates were incubated at $28{ }^{\circ} \mathrm{C}$ for $72 \mathrm{~h}$.

\subsection{Detection of glyphosate breakdown products}

To analyze for breakdown products, $10 \mathrm{~g}$ soil samples were taken from the flasks and added to $40 \mathrm{ml}$ of a solution containing $0.25 \mathrm{~N} \mathrm{NH}_{4} \mathrm{OH}$ and $0.1 \mathrm{~N} \mathrm{KH}_{2} \mathrm{PO}_{4}$

Table 1

Characteristics of the Brazilian soils investigated

\begin{tabular}{|c|c|c|c|c|c|c|c|c|}
\hline \multirow[t]{2}{*}{ Code } & \multirow[t]{2}{*}{ Soil type } & \multirow{2}{*}{$\begin{array}{l}\text { Glyphosate } \\
\text { application } \\
\text { (Years) }\end{array}$} & \multicolumn{6}{|c|}{$\underline{\text { Soil characteristic }}$} \\
\hline & & & Sand $(\%)$ & Silt $(\%)$ & Clay $(\%)$ & $\mathrm{pH}$ & $\begin{array}{l}\text { Organic } \\
\text { matter }(\mathrm{g} / \mathrm{kg})\end{array}$ & $\begin{array}{l}\text { Cation exchange } \\
\text { capacity }(\mathrm{Mmol} / \mathrm{kg})\end{array}$ \\
\hline HTG0 & Hapludult & $\begin{array}{l}\text { No reported } \\
\text { application }\end{array}$ & 41 & 13 & 46 & 5.7 & 23 & 88.3 \\
\hline HTG6 & Hapludult & 6 & 49 & 9 & 42 & 5.9 & 23 & 92.0 \\
\hline HXG0 & Hapludox & $\begin{array}{l}\text { No reported } \\
\text { application }\end{array}$ & 3 & 11 & 86 & 5.6 & 26 & 118.2 \\
\hline HXG11 & Hapludox & 11 & 1 & 8 & 91 & 5.2 & 20 & 92.1 \\
\hline
\end{tabular}


and shaken for $90 \mathrm{~min}$. The mixture was centrifuged at 3000 rev $\mathrm{min}^{-1}$ for $20 \mathrm{~min}$ and the supernatant removed. This procedure was repeated, and the supernatants pooled and acidified to $\mathrm{pH} 2.0$ with $\mathrm{HCl}$ and the volume reduced to less than $5 \mathrm{ml}$ under vacuum in a rotary evaporator in a water-bath set at $60{ }^{\circ} \mathrm{C}$. The concentrated solution was adjusted to $\mathrm{pH}$ 1.8-2.0 with ammonium hydroxide, transferred to a centrifuge tube and centrifuged at $4000 \mathrm{rev} \mathrm{min}^{-1}$ for $10 \mathrm{~min}$. The supernatant was then transferred to a column of cation exchange resin activated with $100 \mathrm{ml} \mathrm{HCl} 0.01 \mathrm{M}$, with flow rate of $2.5 \mathrm{ml} \mathrm{min}^{-1}$. Glyphosate and aminomethyl phosphonic acid (AMPA) were eluted from the column using $5 \times 20 \mathrm{ml}$ of $0.1 \mathrm{M}$ hydrochloric acid, the elutate being evaporated to dryness in a rotary evaporator and re-dissolved in $0.08 \mathrm{M}$ phosphoric acid. Residual glyphosate and AMPA were post-column derivatized using the OPA-MERC reagent and detected using a fluorescence detector ( $E_{x} 350 \mathrm{~nm} ; E_{m} 440 \mathrm{~nm}$ ). Retention times for glyphosate and AMPA were 22 and $44 \mathrm{~min}$, respectively.

\subsection{Statistical analysis}

Treatments were replicated three times in a completely randomized design. Statistical analysis was conducted using the SAS System software (SAS Institute Co.). For comparison of averages the Tukey test was used at the $5 \%$ probability level.

\section{Results and discussion}

\subsection{Glyphosate biodegradation as measured by carbon dioxide evolution}

During incubation of the soil samples (three replications), more carbon dioxide was released from soils to which glyphosate had been added than from controls without added glyphosate (Fig. 1a and b).

For example, the cumulative amount of carbon dioxide $\left(\mu \mathrm{gg}^{-1}\right.$ of soil) released from the soils without added glyphosate (the controls) at the end of the incubation period (day 32) was 0.32 for sample HTG0, 0.39 for HTG6, 0.38 for HXG0 and 0.40 for HXG11, while the amount of carbon dioxide released from soils which had received supplementation with $2.16 \mu \mathrm{g} \mathrm{kg}^{-1}$ of glyphosate was higher at 0.42 for sample HTG0, 0.49 for HTG6, 0.46 for HXG0 and 0.49 for HXG11. The larger amounts of carbon dioxide released in the presence of glyphosate suggest that the soil microbiota is capable of using glyphosate as a carbon source, agreeing with the results of Wardle and Parkinson (1990a) who suggest that carbon dioxide production is related to the decomposition of glyphosate in soil. Souza et al. (1999), observed that the glyphosate was degraded quickly up to the 10th day of incubation, while other authors (Sprankle et al., 1975; Nomura and Hilton, 1977) have reported rapid degradation of glyphosate in the initial period of incubation and suggested that the adsorption of this herbicide to soil particles may lead to it becoming unavailable to soil microorganisms. In contrast, our experiment disagrees with these findings in that the rate of carbon dioxide evolution, and hence glyphosate degradation, was greatest between eight and thirty two days of incubation. It also appears that those soils that came from areas which had previously been treated with herbicides containing glyphosate (HTG6 and HXG11) produced a total amount of carbon dioxide, which was about $10-15 \%$ higher as compared to the soils that had no reported application of glyphosate (HTG0 and HXG0).

\subsection{Microbial activity as measured by fluorescein diace- tate (FDA) hydrolysis}

Microbial activity of the soil, as measured as $\mu \mathrm{g}$ FDA hydrolyzed per gram of soil, increased significantly with time and glyphosate addition (Table 2). Soil samples from areas that had previously been treated with glyphosate had high microbial activity both at the start and end of incubation. The Table 2 shows that there was both a direct (short-term) and indirect (long-term) positive effect of glyphosate on the microbial activity. These results indicate that application of glyphosate rapidly stimulated soil microbial activity in short term and suggested that glyphosate was the direct source of increased microbial activity.

On the other hand, long-term effects of repeated application (six and eleven years) showed an increase in the microbial activity compared to soils with no reported application of glyphosate, showing that repeated application lead to increased microbial activity due the utilization of glyphosate as an available substrate.

The microbial activity is an important factor in the behavior of glyphosate in the soil. According to Heinonen-Tanski (1989) soils with high microbial activity favor the fast biodegradation of glyphosate, and our results for glyphosate degradation as measured by carbon dioxide evolution correlate with our results for soil microbial activity.

\subsection{Enumeration of microorganisms}

The number of microorganisms at the start and end of incubation is shown in Table 3. There were no significant differences for bacteria number, with the exception of HTG6 plus glyphosate. Thus, viable bacteria were generally unaffected by glyphosate. However, the numbers of viable bacteria in soil were low. Probably the 

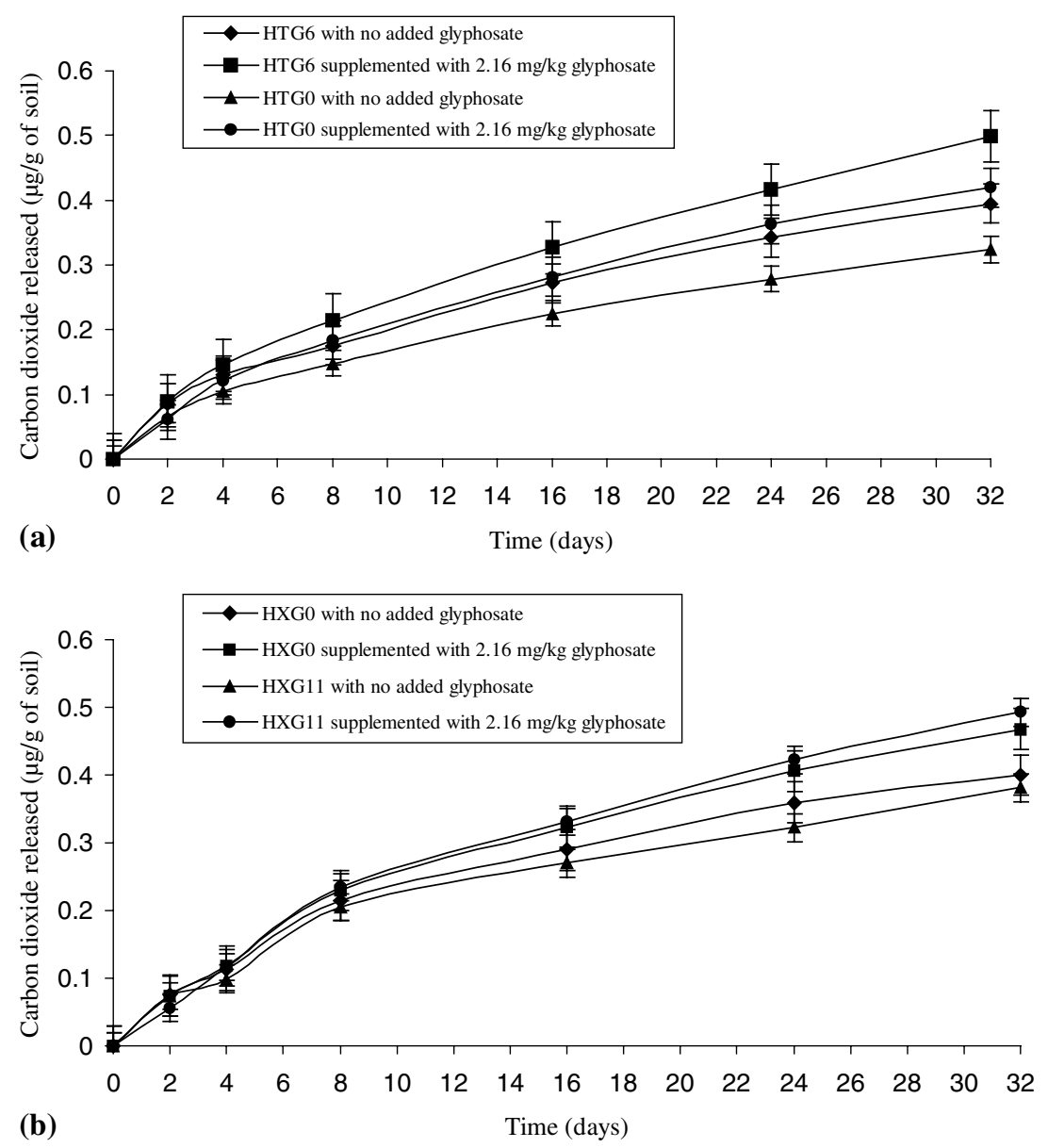

Fig. 1. Evolution of carbon dioxide from Hapludult soil with no reported application of glyphosate (HTG0) and Hapludult soil with six years application of glyphosate (HTG6) (a). Evolution of carbon dioxide from Hapludox soil with no reported application of glyphosate (HXG0) and Hapludox soil with eleven years application of glyphosate (HGX11) (b).

Table 2

Microbial activity of different types of soil as determined by the fluorescein diacetate (FDA) method before and after incubation for 32 days with and without added glyphosate

\begin{tabular}{llll}
\hline Soil type & \multicolumn{2}{l}{ Microbial activity expressed as $\mu \mathrm{g}$ of FDA hydrolyzed per gram of soil } \\
\cline { 2 - 4 } & Day 0 & Day 32 & Soil with no added glyphosate \\
\cline { 2 - 4 } & Soil with no added glyphosate & $\begin{array}{l}\text { Soil supplemented with } 2.16 \\
\mathrm{mg} \mathrm{kg}^{-1} \mathrm{glyphosate}^{(\text {control })}\end{array}$ \\
\hline HTG0 & $29.06 \mathrm{c}$ & $33.99 \mathrm{~b}$ & $41.56 \mathrm{a}$ \\
HTG6 & $48.26 \mathrm{c}$ & $49.39 \mathrm{~b}$ & $55.66 \mathrm{a}$ \\
HXG0 & $27.25 \mathrm{c}$ & $37.49 \mathrm{~b}$ & $46.61 \mathrm{a}$ \\
HXG11 & $50.26 \mathrm{c}$ & $72.45 \mathrm{~b}$ & $78.05 \mathrm{a}$ \\
\hline
\end{tabular}

Values in the same row with the same letter do not differ significantly by the Tukey test $(P \geqslant 0.05)$.

${ }^{\text {a }}$ Soil type key: HTG0 = Hapludult soil with no reported application of glyphosate; HTG6= Hapludult soil with six years application of glyphosate; HXG0 = Hapludox soil with no reported application of glyphosate; HXG11= Hapludox soil with 11 years application of glyphosate.

content of organic matter in the soils favored the heterotrophic microorganisms, as the fungi and actinomy- cetes, while the bacteria had a depletion in the viable cells. 
Table 3

Type and number of microorganisms detected in different soil types before and after incubation for 32 days with and without added glyphosate

\begin{tabular}{|c|c|c|c|}
\hline \multirow[t]{3}{*}{ Microorganism and soil type ${ }^{a}$} & \multicolumn{3}{|c|}{ Colony forming units per gram of soil } \\
\hline & \multirow{2}{*}{$\begin{array}{l}\text { Day } 0 \\
\text { Soil with no added glyphosate }\end{array}$} & \multicolumn{2}{|l|}{ Day 32} \\
\hline & & $\begin{array}{l}\text { Soil with no added glyphosate } \\
\text { (control) }\end{array}$ & $\begin{array}{l}\text { Soil supplemented with } 2.16 \\
\mathrm{mg} \mathrm{kg}^{-1} \text { glyphosate }\end{array}$ \\
\hline \multicolumn{4}{|l|}{ Bacteria } \\
\hline HTG0 & $0.50 \times 10^{5} \mathrm{a}$ & $2.20 \times 10^{5} \mathrm{a}$ & $1.80 \times 10^{5} \mathrm{a}$ \\
\hline HTG6 & $0.50 \times 10^{5} \mathrm{a}$ & $4.00 \times 10^{5} \mathrm{a}$ & $7.00 \times 10^{5} \mathrm{~b}$ \\
\hline HXG0 & $9.10 \times 10^{5} \mathrm{a}$ & $4.90 \times 10^{5} \mathrm{a}$ & $6.30 \times 10^{5} \mathrm{a}$ \\
\hline HXG11 & $8.50 \times 10^{5} \mathrm{a}$ & $1.05 \times 10^{6} \mathrm{a}$ & $7.80 \times 10^{5} \mathrm{a}$ \\
\hline \multicolumn{4}{|l|}{ Fungi } \\
\hline HTG0 & $1.00 \times 10^{4} \mathrm{c}$ & $1.60 \times 10^{4} \mathrm{~b}$ & $4.50 \times 10^{4} \mathrm{a}$ \\
\hline HTG6 & $0.50 \times 10^{4} \mathrm{c}$ & $1.70 \times 10^{4} \mathrm{~b}$ & $3.50 \times 10^{4} \mathrm{a}$ \\
\hline HXG0 & $0.62 \times 10^{4} \mathrm{c}$ & $0.92 \times 10^{4} \mathrm{~b}$ & $3.30 \times 10^{4} \mathrm{a}$ \\
\hline HXG11 & $0.87 \times 10^{4} \mathrm{c}$ & $0.80 \times 10^{4} \mathrm{~b}$ & $5.30 \times 10^{4} \mathrm{a}$ \\
\hline \multicolumn{4}{|l|}{ Actinomycetes } \\
\hline HTG0 & $0.24 \times 10^{6} \mathrm{c}$ & $0.64 \times 10^{6} \mathrm{~b}$ & $5.40 \times 10^{6} \mathrm{~b}$ \\
\hline HTG6 & $0.40 \times 10^{6} \mathrm{c}$ & $1.50 \times 10^{6} \mathrm{~b}$ & $2.40 \times 10^{6} \mathrm{a}$ \\
\hline HXG0 & $0.12 \times 10^{6} \mathrm{c}$ & $0.07 \times 10^{6} \mathrm{~b}$ & $0.55 \times 10^{6} \mathrm{a}$ \\
\hline HXG11 & $0.80 \times 10^{6} \mathrm{~b}$ & $0.34 \times 10^{6} \mathrm{~b}$ & $2.50 \times 10^{6} \mathrm{a}$ \\
\hline
\end{tabular}

Values in the same row with the same letter do not differ significantly by the Tukey test $(P \geqslant 0.05)$.

${ }^{\text {a }}$ Soil type key: HTG0 = Hapludult soil with no reported application of glyphosate; HTG6= Hapludult soil with six years application of glyphosate; HXG0 = Hapludox soil with no reported application of glyphosate; HXG11= Hapludox soil with 11 years application of glyphosate.

In the case of fungi, application of glyphosate resulted in higher counts. According to Wardle and Parkinson (1990b), glyphosate can influence the number of fungi directly and, indirectly, by affecting the interaction of fungi with other microorganisms. These results indicate that fungi may use glyphosate as a nutrient and energy source. Actinomycetes showed a significant increase with time, mainly in the presence of glyphosate.

\subsection{Detection of glyphosate breakdown products}

Aminomethyl phosphonic acid (AMPA), a molecule which has a lower rate of degradation than glyphosate, has been reported by Forlani et al. (1999) as the major metabolite of glyphosate. The amount of glyphosate and AMPA detected in the soils before and after incubation are shown in the Table 4 . The quantity of glyphosate recovered at day 0 after addition of $2.16 \mathrm{mg} \mathrm{kg}^{-1}$ was similar for the HT soils, although less was recovered from the HX soils, probably due to the presence higher clay content of this type of soil (Table 1). This indicates that there was less bioavailability of glyphosate in the HX soils. There were no differences between soils which had previously been treated with glyphosate and those which had not. After 32 days, the amount of residual glyphosate in the HT soils was low, and there was no difference between soil which had previously received
Table 4

Amounts of glyphosate and aminomethyl phosphonic acid (AMPA) detected in different types of soil before and after incubation for 32 days

\begin{tabular}{llll}
\hline Soil type & \multicolumn{3}{l}{ Quantity $\left(\mathrm{mg} \mathrm{kg}^{-1}\right)$} \\
\cline { 2 - 4 } & Day 0 & Day 32 \\
\cline { 2 - 4 } & Glyphosate & Glyphosate & AMPA \\
\hline HTG0 & 2.116 & 0.148 & 0.504 \\
& $( \pm 0.03)$ & $( \pm 0.03)$ & $( \pm 0.64)$ \\
HTG6 & 2.376 & 0.139 & 0.788 \\
& $( \pm 0.10)$ & $( \pm 0.10)$ & $( \pm 0.47)$ \\
HXG0 & 1.455 & 0.202 & 0.446 \\
& $( \pm 0.01)$ & $( \pm 0.01)$ & $( \pm 0.60)$ \\
HXG11 & 1.450 & 0.461 & 0.677 \\
& $( \pm 0.01)$ & $( \pm 0.01)$ & $( \pm 0.53)$ \\
\hline
\end{tabular}

Mean plus standard deviation in parentheses $(n=3)$ are given.

${ }^{\text {a }}$ Soil type key: HTG0 $=$ Hapludult soil with no reported application of glyphosate; HTG6= Hapludult soil with six years application of glyphosate; HXG0 = Hapludox soil with no reported application of glyphosate; HXG11 = Hapludox soil with 11 years application of glyphosate.

glyphosate and soil which had not. Residual glyphosate was about twice as high in the HXG0 soil and four times as high in the HXG11 soil than in the HT soils.

The metabolite AMPA was detected in all the soil samples after 32 days of incubation in amounts about 
1.5 times higher in soil collected from sites which had previously been treated with glyphosate than in soils which had not been exposed to glyphosate.

These results strongly indicate that glyphosate was biodegraded by soil microorganisms with the formation AMPA, and that the herbicide had positive effect on the soil microbial activity in short- and long-term. Future studies may shed light on the complex interactions occurring between microorganisms during the biodegradation of glyphosate.

\section{Acknowledgements}

We are grateful to Lourdes S. Souza (Pesticides Residues Laboratory, EMBRAPA, CNPMA, Brazil) for her technical assistance, Dr. Ricardo Victoria Filho for providing access to ESALQ Horticulture Farm and Dr. Nelson Fonseca from IAPAR/PR for collection of samples. This work was supported by grant 00/06299-8 from Fundação de Amparoà Pesquisa do Estado de São Paulo (FAPESP), the authors A.S.F. Araújo and R.T.R. Monteiro being supported by personal grants from FAPESP and CNPq funding agency.

\section{References}

Bartha, R., Pramer, D., 1965. Features of a flask and method for measuring the persistence and biological effects of pesticides in soil. Soil Sci. 100, 68-70.

Busse, M.D., Ratcliff, A.W., Shestak, C.J., 2001. Glyphosate toxicity and the effects of long-term vegetation control on soil microbial communities. Soil Biol. Biochem. 33 (12-13), 1777-1789.

Forlani, G., Mangiacalli, A., Nielsen, E., Suardi, C.M., 1999. Degradation of the phosphonate herbicide glyphosate in soil: evidence for a possible involvement of unculturable microorganism. Soil Biol. Biochem. 31 (7), 991-997.
Haney, R.L., Senseman, S.A., Hons, E.M., Zuberer, D.A., 2000. Effect of glyphosate on soil microbial activity and biomass. Weed Sci. 48, 89-93.

Heinonen-Tanski, H., 1989. The effect of temperature and liming on the degradation of glyphosate in two arctic forest soils. Soil Biol. Biochem. 21 (2), 313-317.

Jahnel, M.C., Cardoso, E.J.B.N., Dias, C.T.S., 1999. Determinação do número mais provável de microrganismos do solo pelo método de plaqueamento por gotas. R. Bras. Ci. Solo 23 (3), 553-559.

Jonge, H., Jonge, L.W., 1999. Influence of $\mathrm{pH}$ and solution composition on the sorption of glyphosate and prochloraz to a sandy loam soil. Chemosphere 39 (5), 753-763.

Krzysko-Lupicka, T., Orlik, A., 1997. The use of glyphosate as the sole source of phosphorus or carbon for the selection of soil-borne fungal strains capable to degrade this herbicide. Chemosphere 34 (12), 2601-2605.

Nomura, N.S., Hilton, H.W., 1977. The adsorption and degradation of glyphosate in five Hawaiian sugarcane soils. Weed Res. 17, 113-121.

Schnürer, J., Rosswall, T., 1982. Fluorescein diacetate hydrolysis as a measure of total microbial activity in soil an litter. Appl. Environ. Microbiol. 43, 1256-1261.

Souza, A.P., Ferreira, F.A., Silva, A.A., Cardoso, A.A., Ruiz, H.A., 1999. Respiração microbiana do solo sob doses de glyphosate e de imazapyr. Planta Daninha 17 (3), 387-398.

Sprankle, P., Meggitt, W.F., Penner, D., 1975. Adsorption, mobility, and microbial degradation of glyphosate in the soil. Weed Sci. 23 (3), 229-234.

Stratton, G.W., Stewart, K.E., 1992. Glyphosate effects on microbial biomass in a coniferous forest soil. Environ. Toxicol. Water Qual. 17 (3), 223-236.

Wardle, D.A., Parkinson, D., 1990a. Effects of three herbicides on soil microbial biomass and activity. Plant Soil 122, 2128.

Wardle, D.A., Parkinson, D., 1990b. Influence of the herbicide glyphosate on soil microbial community structure. Plant Soil 122, 29-37.

Wiren-Lehr, S., Komoba, D., Glabgen, W.E., 1997. Mineralization of $\left[{ }^{14} \mathrm{C}\right]$ glyphosate and its plant-associated residues in arable soils originating from different farming systems. Pesticide Sci. 51 (4), 436-442. 